\title{
Measuring women's social position: the importance of theory
}

Gender, science and politics

The classification of women's social position, an apparently technical issue, involves many of the classic themes in social science, where science and politics, the prescriptive and the descriptive, appear indissolubly entangled. Increasingly it has come to be regarded as unacceptable to use the occupation of a husband, male partner or father to allocate women to a social class. However, there is evidence that many social and political attitudes, aspects of consumer behaviour and health are strongly influenced by the social position of male next of kin. ${ }^{1}$ Little as we may wish women's fate to depend on men's, much of our observation of society indicates that to some extent it still does. Of course, if women's equality were unproblematic, we would not need a political movement committed to it. Such movements, which reveal prejudice and injustice for what movements, which reveal prejudice and injustice for what
they are, have often been of benefit to science, because power and domination have a profound effect on the growth of knowledge. ${ }^{2}$

\section{The relevance of employment}

In this edition of the journal, Krieger systematically compares the "conventional" (some might say sexist) approach to social classification of women, which allocates social class on the basis of the husband or male partner, to a "gender neutral" approach and a "combined" approach. ${ }^{3}$ This is more than arguing over whether women are better This is more than arguing over whether women are better
classified according to their own or their husbands' classified according to their own or their husbands occupation. In the mid-1980s women's labour force
participation was lower than it is at present: $32 \%$ of women
at any one time were keeping house and $24 \%$ were working at any one time were keeping house and $24 \%$ were working part time only; (by 1997 the respective proportions were $22 \%$ and $15 \%$ (Social Trends 1998 table 4.2 p 75)). Insofar as we regard work as the relevant "exposure" in studies of social aetiology, there were in fact rather good reasons for doubting whether it could have the same effect on women as men, merely on the grounds of a simple dose response argument. ${ }^{4}$

The argument went something like this: Why would we expect there to be class differences in health of men or women? Class is allocated according to occupation. Occupation affects health because of a combination of physical hazard exposures, psychosocial factors ("stress") and economic factors, that is, the non-work environment to which income gives access (housing quality, neighbourhood quality, leisure activities, social participation). Now, if $40 \%$ or $50 \%$ of women were either not in paid employment at all or only working part time, this had two implications. They were either not exposed at all, or less exposed to the physical and psychosocial hazards; and the income of their in part determined by their own income. Health gradients in women tend to be steeper when social class is allocated according to the occupation of the male partner than when that of the woman herself is used ${ }^{5} 6$; indicating, to some, the predominance of "way of life" over "work". "The point at issue is whether work has a weaker effect on way of life for women than for men.

Social divisions at work and home

The occupational structure for women has become "polarised", with a greater degree of income inequality and an increase in both the numbers occupying well paid high status jobs such as medicine and law at one end of the spectrum, as well as in the numbers occupying poorly paid low status occupations such as catering and cleaning ${ }^{8}$ (some of the latter employed by the former in the rapid return of domestic service after its disappearance in the 1960 and $\left.1970 \mathrm{~s}^{9}\right)$. A similar polarisation has of course also taken place in the male labour force, ${ }^{10}$ the major difference being that more prosperous women employ poor women to care for their homes and children whereas men can still, to a much greater extent, depend on unpaid female labour for domestic services. ${ }^{11}$ This must be the major difference that needs to be taken into account when trying to understand differences in health inequality between men and women. There is no established social role for men who provide sexual or domestic service in exchange for a higher standard of living than they could otherwise aspire to. Such cases res are the subject of comedy. One quite well known film, "Mrs Doubtfire", in order to show a man looking after his own children full time, devises a situation in which he is divorced by his wife and re-appears disguised as a female servant. Although the definition of the marital arrangement as an exchange of domestic services for material security may be becoming less accepted in industrial societies in its pure form, it is still a culturally recognisable pattern desired by many men, as witnessed by the existence of a market for by many men, as witnessed by the existence of a market for perhaps rather extreme limiting cases may be borne in mind when considering the merits of different ways to characterise women's social position.

When we consider the social factors in the health of women, it would therefore be mistaken to forget influences cmanating from the wider society beyond the workplace, or one thing, it is perfectly clear that women do not (yet) have the power to oblige men to undertake an equal share of domestic labour and child care, no matter how high the status of their employment. ${ }^{913}$ We cannot ignore the ways in which the social epidemiology of women's health is still affected by traditional norms, beliefs and role models. Krieger's paper shows that we need to be aware of both sides of this when considering health inequality in women.

\section{From description to explanation}

Krieger's paper encourages us to look forward to an approach to health inequality research that is more firmly based in social theory. In this way, further progress can be made away from description of social variations in health and towards explanation. The theoretical approach favoured in the paper is one that focuses on where a given occupation is located in the wider system of relations of production in industrial societies.

To a very great extent, it is occupation that determines two of the other major dimensions of social inequality: material living standards and status. But they do not coincide exactly. Membership of certain ethnic groups for example may give access to a degree of privilege in terms of status that is denied others in the same occupation. is antage of examining each dime inequality separately is most evident in the study of women's health. This strategy allows us to classify household status, for example, according to a gender neutral method (according to the "dominant partner") and ask whether patterns of health and health behaviour follow the status of their household or the prevalent pattern in the occupational group of each partner ${ }^{14}$ Are nurses, for example (an tionalgroup of each partner." Are nurses, $f$ Occupation in which smoking United Kingdom) less likely to smoke if they live with managers than with bus drivers? 
It is increasingly convincingly argued that there are psychosocial effects lying on the pathways leading from social position to chronic disease $\mathrm{e}^{15-18}$; we know less about which aspects of social situations are most hazardous. ${ }^{19}$ From the point of view of policy debates on health inequality, it is of great relevance to know whether the same working conditions, such as high pace of work or long working hours for example, have different effects on men or women with different levels of prestige. Can having a high status in one's community defend against work stress, or even strengthen the immune responses to purely biological hazards ${ }^{20}$ Alternatively, could greater lower standing in the community, as is suggested by the recent report of unexpectedly low mortality in the self employed (regardless of status)? $?^{21}$ These questions only become clear when greater attention is paid to the methods by which we measure social position and circumstances for both women and men.

MEL BARTLEY International Centre for Health and Society, Department of Epidemiology

Mel Bartley gratefully acknowledges the support of the UK Medical Research
Council (grant no G8802774) and Economic and Social Research Council Council (grant no G8802774) and Economic and So
(Health Variations Programme grant no L128251001).

Marshall G, Roberts S, Burgoyne C, et al. Class, gender
hypothesis. European Sociological Review 1995;11;1-15 2 Foucault M. The birth of the clinic. London: Tavistock, 1976.

and householdbased measures of social class to assess class inequalities in women's health
a methodological study of 684 US women. E Epidemiol Community Health 1999;53:612-23.
4 Martikainen P. Mortality and socioeconomic-status among Finnish women Population Simdies-A Younal of Domography 1995,49.71-90.

. $221-4$

6 Dahl E. Inequality in health and the class position of women: the Norwegian

experience. Sociology of Health and Illness $1991,13: 491-505$. miol Community Health 1978;32:73-8. Davies H, Joshi H. Gender and income inequality in the UK 1968-1990: the feminization of meaning or of poverty? Yournal of the Royal Statistical Society

9 Gregson N, Lowe M. Servicing the middle classes: class, gender and domestic labour in contemporary Britain. London: Routledge, 1994.

versity Press, 1997.
Ward C, Dale A, Joshi H. Combining employment with childcare: An escape Asian-Australian marriages. Feminist Review 1996;52:53-68.

13 Speakman S, Marchington M. Ambivalent patriarchs: shiftworkers, 'bread-
winners' and housework. Work Employment and Society 1999;13:83-106. 14 Bartley M, Sacker A. Firth D, et al. Social position, social roles and women's health in England: changing relationships 1984-1993. Soc Sci Med 1999;48:99-115.

15 Marmot M, Ryff CD, Bumpass LL, et al. Social inequalities in health: nex questions and converging evidence. Soc Sci Med 1997;44:901-10.

work et al. Long-term psychosocia Public Health 1996;86:324-31.

17 Marmot MG, Bosma $\mathrm{H}$, Hemingway H, et al. Contribution of job control nd other risk factors to social variations in coronary heart diseas

8 Bosma $\mathrm{H}$, Peter R, Siegrist J, et al. Two alternative job stress models and the risk of coronary heart disease. Am F Public Health 1998;88:68-74. Goffman E. On cooling the

Wyilinary 1952,15.451-63.

Fitzpatrick J, Dollamore G. Examining adult mortality rates using the
National Statistics Socio-Economic Classification. Health Statistics Ouarterly 1999;2:33-40. 